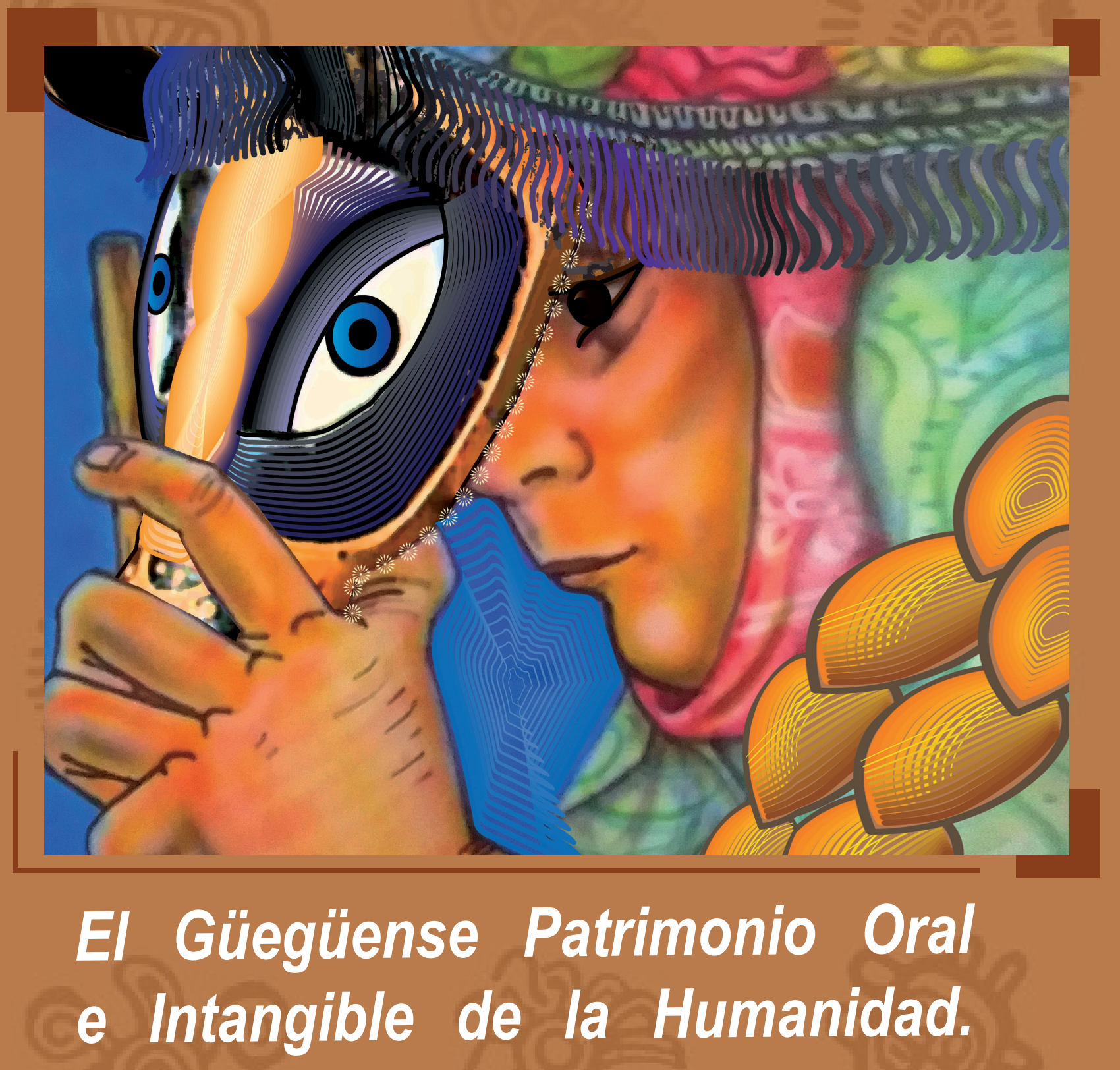

Interpretación Sociocultural de la Danza 


\section{El Güegüense Patrimonio Oral e Intangible de la Humanidad.}

\section{El Güegüense Oral and Intangible Heritage of Humanity.}

Juana Gricelda Téllez Vado

Antropóloga Social, Docente Investigadora

Departamento de Antropología

Facultad de Humanidades y Ciencias Jurídicas

UNAN-Managua

ID Orcid https://orcid.org/0000-0003-2810-0110

jugrictelva@gmail.com

Recibido: 26-06-2021

Aceptado: 26-06-2021

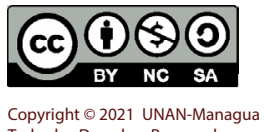

Copyright $\odot 2021$ UNAN-Managua
Todos los Derechos Reservados.

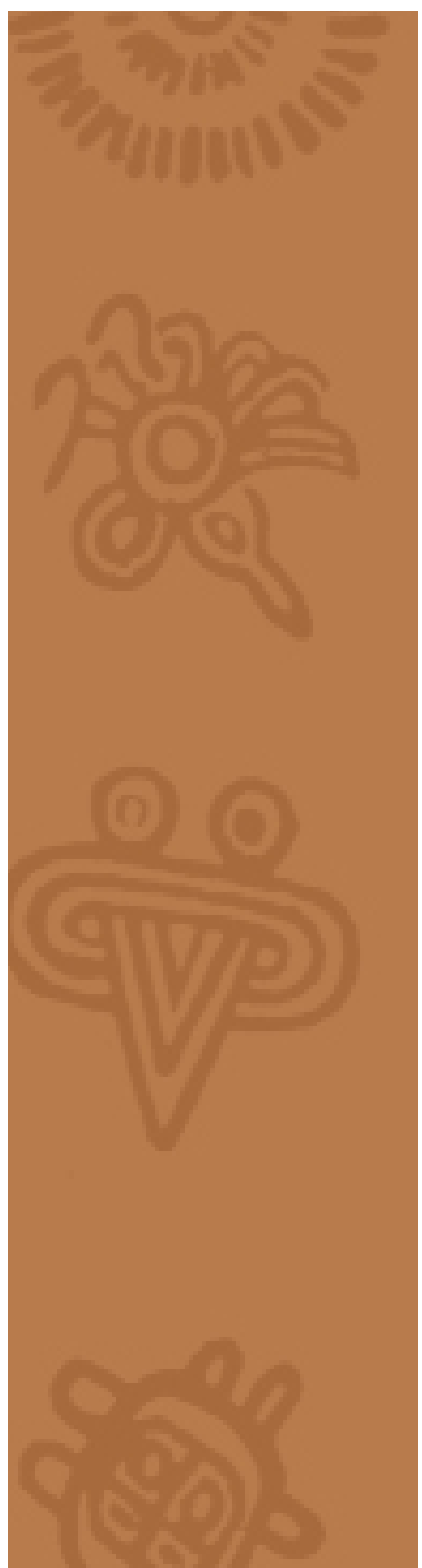

\section{Introducción}

El presente trabajo fue el resultado del VI Congreso Centroamericano de Antropología "Centroamérica Hacia La Transformación Sociocultural" Dedicado al Dr. Alejandro Dagoberto Marroquí, San Salvador, 15 al 18 de agosto 2006; ponencia dedicada la obra de teatro popular y colonial "El Güegüense o Macho Ratón", que en noviembre del 2005 la UNESCO lo reconoce como Patrimonio Oral e Intangible de la Humanidad.

Nicaragua contribuye por segunda vez en la lista de obras y sitios que establecen la riqueza material y espiritual de la especie humana. La primera vez, fue la declaratoria de patrimonio de la humanidad a "Las Ruinas de León Viejo" y de esta forma Nicaragua está orgullosa con este acervo cultural.

"El Güegüense" es la obra que da a conocer la identidad mestiza y recoge las manifestaciones de la tradición oral, prácticas sociales, los rituales, las festividades y la mitología, junto con la representación del viejo o güegüe. Es el símbolo de los aconteceres guardados en la memoria de nuestros antepasados indígenas que han sido trasmitidos de manera oral de generación en generación, representados posteriormente durante la colonia española en las fiestas de los pueblos del Pacífico de Nicaragua y durante la vida independiente se continuaron sus manifestaciones, enriquecidos sus textos con música y expresiones de colorido. Su contenido y sus expresiones se han reproducido en las técnicas propias de la artesanía tradicional y artística recreada permanentemente en función de su interacción con la naturaleza, con su historia y el mismo universo. En su conjunto revela la rebeldía en contra del sistema impuesto de la época colonial y enfoca la crítica a la estructura política y social de la época.

Por estas razones las autoridades del gobierno de Nicaragua, presentaron formalmente la candidatura de "El Güegüense" para incluirlo en la lista de patrimonios culturales de la UNESCO; proceso de selección que duró dos años, para lo cual se presentó una información técnica que incluye: la ubicación geográfica de la obra, su descripción, estilo, escuela que la originó, influencias artísticas y antecedentes históricos. Es así, que entre el 21 y el 24 de noviembre, un jurado de 18 miembros -ninguno nicaragüense-, presidido por la Princesa Basma Bint Talal de Jordania, analizó y evaluó 70 candidaturas con sus respectivos expedientes y eligió 43 obras maestras, como ejemplos excepcionales de la riqueza y la diversidad del Patrimonio Cultural e Inmaterial de la Humanidad, entre ellas El Güegüense de Nicaragua. 


\section{Origen del documento escrito}

La UNESCO describe los valores de El Güegüense y lo caracteriza como un "drama satírico", considerándola como "una de las más significativas expresiones latinoamericanas de la época de la Colonia". En el personaje del viejo o güegüe, es decir, el Güegüense, se aprecia su capacidad para "socavar la autoridad española", por eso en Nicaragua "hacerse el güegüense" significa actualmente, ser capaz de ese hábil desafío de socavar el poder y la autoridad.

En la obra se hace mención de la actitud cordial y cortés frente al poderoso y el extranjero: "Dios misericordioso guarde a Usted, Señor Gobernador", rápidamente se dan expresiones de bromas y risas a las espaldas del gobernador. Y eso mismo, ocurre en Nicaragua, el Güegüense siguió vigentes siglos después. Por eso la distinción de la obra, la UNESCO lo fundamenta dentro del patrimonio intangible de la humanidad, por su representación y la resistencia indígena pacífica ante la imposición de la autoridad y cultura de los españoles.

Durante largo tiempo, los pueblos carecieron de un modo de vida propia, definido y congruente, el viejo modo de vida había muerto como fuerza integradora y no había surgido entretanto uno nuevo; desgastados por las epidemias, llevados a la desesperación por la esclavitud, se transformaron en meros rebaños humanos cuyos miembros no tenían en su vida otra alternativa que cumplir el destino que les era impuesto; sin embargo, conservaron y transmitieron de generación en generación fragmentos de los viejos valores cuya actualización en la conducta y práctica resultaba imposible, pero que aún eran respetados (Ribeiro, 1969)

Haciendo mención de algunos estudiosos de la obra de El Güegüense, Juan Eligio de la Rocha lingüista nicaragüense (1815-1873) fue el primero que descubrió el manuscrito (Saballos Ramírez, 2013) en algún lugar de la Meseta de Los Pueblos, región del Pacifico de Nicaragua, y que parece ser la producción de un Fraile español o un indígena, don Juan Eligio se dedicó a investigar las lenguas aborígenes de Nicaragua para interpretar el escrito. El segundo descubridor fue el alemán Doctor Karl Hermann Berendt (1817-1878), quien transcribió una versión en inglés del manuscrito de Juan Eligio de la Rocha. El tercero fue el filólogo norteamericano Daniel Garrison Brinton (1837-1899) que en 1883 publicó en Filadelfia, Estados Unidos, el manuscrito de Berendt.

La primera noticia escrita y publicada sobre El Güegüense aparece en 1883 cuando Daniel Brinton publica el manuscrito del doctor Hermann Berendt. A partir de esta primera publicación, el texto escrito fue mencionado por algunas personas ligadas a la literatura y a otras ramas de la ciencia; esto fue motivo de polémicas entre otros intelectuales y posteriormente sufre períodos de olvido y períodos de resurgimiento. Se han hecho varias publicaciones, interpretaciones, versiones y traducciones de este primer manuscrito (Briton, 1883) 


\section{Clasificación literaria}

La UNESCO lo declara al Güegüense como obra teatral, pero se ha clasificado de muy diferentes maneras: "comedia bailete, "drama épico indígena" (Dávila Bolaños, aput Urbina, 62), "farsa cómica bailable", "bailete dialogado, Brinton en 1883, afirma que "era representado antes de principios del siglo $(\mathrm{XX})$ y con este único dato se da por terminada su historia". Un año después, en 1884, José Martí la calificó como "comedia maestra después de la conquista, (escrita) en un dialecto burdo mezcla de castellano bajo y náhuatl corrompido" (aput Arellano; 1983, contraportada).

Unos años después, Rubén Darío lo calificó como obra de una simplicidad primitiva donde alternan los diálogos dentro de un marco monótono y pintoresco. (aput Arellano, 1991, 12). Estas opiniones de Brinton, Martí y Darío, sumadas a la del antropólogo Lothrop que considera como "dramita que se distingue por su trama vulgar, pero con mucho humor, basado especialmente en el juego de palabras", sitúan a El Güegüense en el espacio de las literaturas marginales que no siguen los cánones de la literatura europea, subrayan la simplicidad primitiva, lo pintoresco, la trama vulgar y dialecto. Cid-Pérez opina que "es una obra en la que no podemos pensar en valores literarios, sino en valores folclóricos", es decir, todos ellos la enmarcan dentro de lo folclórico y lo popular para ser fosilizada y guardada como pieza de museo, producida no por un autor sino por el pueblo burdo (Briton, 1883).

Todas las significaciones del "Güegüense", son una muestra de las contradicciones como texto literario, es la lucha entre su supervivencia y su muerte. Por un lado, por sobrevivir como texto nacido en una época y como expresión de una cultura determinada, y por otro, para ser relegado por la literatura canónica como texto arcaico marginal con valor solamente para los antropólogos, historiadores y folcloristas. "El Güegüense habla por el pueblo y defiende a su pueblo".

Si a lo largo de los años el texto escrito ha sufrido altibajos en su discusión y publicación, su discurso oral se ha repetido de manera constante de generación en generación. La presentación oral de esta obra anónima -como dice el nicaragüense Pablo Antonio Cuadra- "se ha 'mantenido en taquilla' desde el Siglo XVI, en que fue probablemente escrita, hasta nuestros días". Y afirma que es una obra viva "porque su protagonista es un personaje que el pueblo nicaragüense lleva en la sangre".

La inserción de "El Güegüense" como texto dentro de la literatura nacional, se inició en la década de los años 40 cuando un grupo de intelectuales en León "Ciudad Letrada"-como dice Ángel Rama- lleva a cabo un proyecto de revalorización cultural, recuperando todo aquello catalogado como folclórico; esto motivó a la búsqueda de fuentes populares, intentando forjar una embrionaria identidad cultural: "Nosotros buscábamos nuestro arte nacional entre los pequeños vestigios (...) que habíamos heredado del tiempo colonial" (Joaquín Pasos; aput E. Cardenal 12). 


\section{Raíces}

Revista Nicaragüense de Antropología Año 5 No.9| 2021 Enero - Junio

De esta manera, El Güegüense comienza a ser incorporado a la literatura nacional. En 1942 se tradujo y se editó en español la versión inglesa de Brinton; posteriormente en los años 50, se graba la música, y en 1969 se registra el texto oral. La expresión de la obra se consolida cuando en ese mismo año, Pablo Antonio Cuadra en su libro El Nicaragüense incluye un artículo sobre el personaje de El Güegüense, acuñándose posteriormente la frase: "El Güegüense que llevamos adentro" justifica cualquier acto de burla, de astucia de bufonada de familiarización o de irrespeto a la autoridad. Su punto culminante lo alcanza en 1974, centenario del manuscrito de Berendt, cuando se dan muchas discusiones, representaciones en las escuelas y sirve de tema a los pintores nacionales.

\section{Expresión actual del Güegüense}

El Güegüense como personaje y obra de teatro se practica en los pueblos de la Meseta de los Pueblos: Carazo; Catarina, Diriá y Diriomo, Niquinohomo, Masatepe, San Marcos, Jinotepe, y Diriamba. Para unos, es en Diriamba donde los pobladores por tradición y fe lo han sabido guardar como patrimonio, como tesoro para todos los nicaragüenses; cada año del 17 al 27 de enero es presentado por grupos autóctonos no profesionales, es decir gente del pueblo durante las fiestas patronales dedicadas a San Sebastián. Además, otros grupos artísticos profesionales lo presentan en diversos escenarios como el Teatro Nacional Rubén Darío, y actualmente se presenta una parte de la obra, a manera de danza en los diferentes Centros Universitarios.

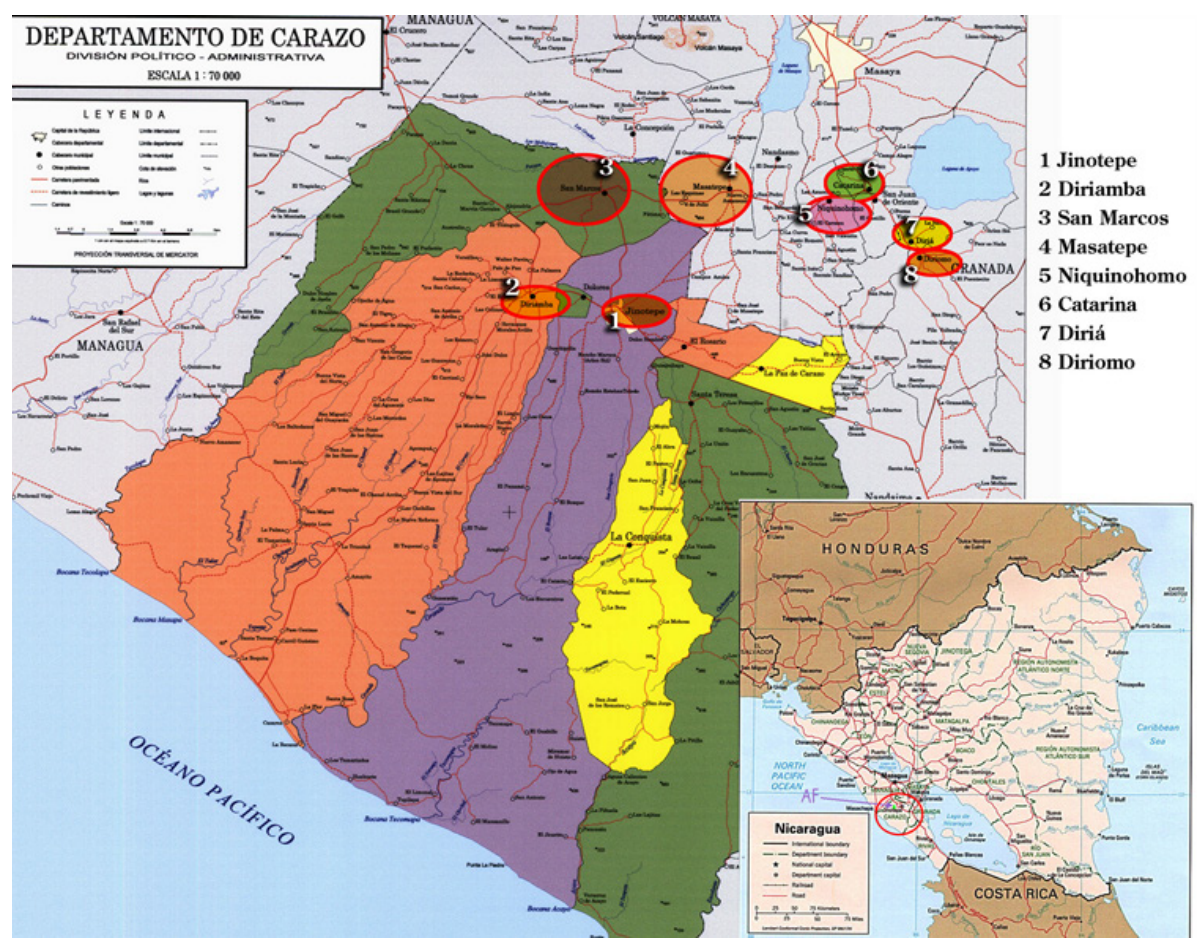


La obra gira alrededor de encuentros entre El Güegüense (cuyo nombre se deriva del término náhuatl güegüe, que es la persona anciana de gran influencia), sus dos hijos y las autoridades coloniales representadas por el Gobernador Tastuanes y el Alguacil. El Güegüense es traído ante el Gobernador por el Alguacil Mayor por entrar sin permiso a su provincia, pero la jactancia y las promesas del astuto Güegüense lo ayudan a escapar del castigo y en cambio logra efectuar un casamiento de su hijo mayor con la hija del gobernador. El interés de la obra no está en el complot, que es trivial, sino en el juego inteligente de maniobras verbales y en el humor.

La obra es presentada por veinticuatro participantes, distribuidos en la siguiente forma: 12 machos con máscaras, 7 españoles con máscaras, 2 damas y 3 músicos; la cual está referida al baile original que se presenta durante las festividades patronales de San Sebastián en Diriamba. Los violines, las guitarras y los tambores proporcionan el acompañamiento musical. Los trajes, las máscaras de madera, los sombreros y otras cualidades distinguen los varios caracteres. Por ejemplo, El Güegüense o Macho Ratón es representado por un personaje de cabeza del caballo derivado de la tradición popular indígena, igual a los otros Machos, pero lleva un azote en la mano y los enmascarados procedentes del Viejo Continente con rostros blancos, ojos azules y largos bigotes con trajes propios de la época colonial. Forman parte de la vestimenta de los Machos: penachos de cabuya, pintado en negro, café, rojo, amarillo y blanco; máscaras de macho (de madera: cedro o acetuno); pañuelos, dos a cada lado de cada bailante; rosas de plástico grandes; flores de papel brillantes, varios colores; cintas de varios colores; chalecos negros, adornados con: leontinas, cadenas y adornos; cofre pequeño para el macho viejo. La vestimenta de los de adentro: capoteras; ligero, o delantal con moneda; centros; pañuelos grandes; gurriones adornados con flores y collares; rosas grandes; sombreros adornados con monedas; flores de plástico y contrabandos con cintas. Los Sombreros son forrados de tela de pana o fieltro, y llevan adornos de monedas, cordones dorados y plateados, y flecos. Los ligeros de pana, con flecos, y adornos de monedas de "oro y plata". La capotera o capa es un pañuelo grande de seda, con trencillas. La vestimenta de las damas: vestidos largos con mangas largas, color celeste o rosado y coronas.

Nuestros aborígenes, antes de la llegada de los conquistadores españoles, se gobernaban por el Consejo de Ancianos y el anciano, hombre de experiencia, era el que sabía, conocía y resguardaba las tradiciones, las creencias, la astronomía para la agricultura, la botánica, las leyes, los mitos de aquellos pueblos. Ellos tenían al maíz como dios, comida, bebida y como autor de los hombres, el maíz es la semilla de América.

En la época colonial, el Güegüense indígena había perdido su mundo y pasado a las encomiendas, a formar parte de los naboríos, hombres de trabajo: arrieros, jornaleros, sembradores, buhoneros, al servicio de las nuevas autoridades. Si el indígena tenía mala fama, belicoso, haragán y borracho, pasó peor con los mestizos, porque ni siquiera tenían un status legal; los encomenderos los acusaban de ladrones, procaces, pícaros y deslenguados. Eran marginales. Pero la despoblación indígena casi sólo vino dejando en el Nuevo Mundo a los primeros mestizos, a los hijos de las mujeres indígenas y los españoles, soldados y conquistadores y después el Continente americano todo vino a ser poblado por mestizos. 


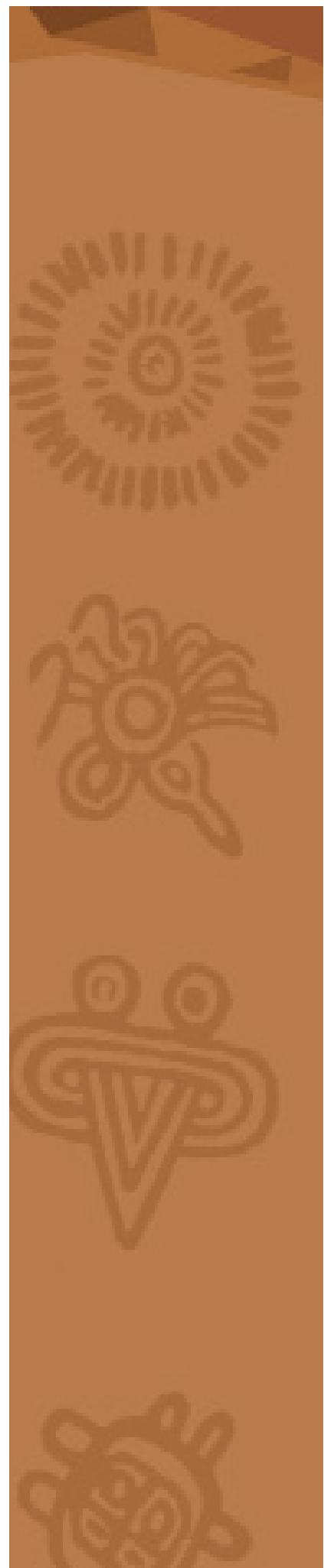

El indio, la india y los españoles que eran mestizos en Europa, vinieron a ampliar el mestizaje. "El Güegüense" representa al mestizo y por eso este reconocimiento mundial es tan importante y trascendente, ya que reivindica a esta nueva casta descalificada y excluida por mucho tiempo. La Lengua del pueblo nicaragüense es reconocida y valorada como un aporte a la humanidad, como un aporte a la lengua castellana o española y como un aporte a la lengua de américa.

De acuerdo al contenido y la significación de El Güegüense, la tradición en Nicaragua y la valoración de la UNESCO, se entrevistaron estudiantes de Antropología Social, de los cursos de Nivelación y Filología y Comunicación; expresaron conocer a El Güegüense y opinaron que "El Güegüense es un personaje burlesco de su desgracia y de la desgracia ajena y por lo tanto alegre, que trata de desquitarse con sus burlas"; "es lo que llevamos muy arraigado en nuestro ser, que de una u otra forma lo damos a conocer en nuestro carácter, principalmente el de la parte burlesca"; "Es parte de la idiosincrasia, es la forma de hablar, los gestos y en el segundo sentido que le damos a las cosas, refleja el criterio de la expresión burlesca hacia nuestros semejantes"; "es el gran viejo hablador, el que habla mucho, como Ricardo Mayorga (boxeador nicaragüense. Título mundial 2005) y los Políticos"; "representa la fusión del indígena y el español pero en él sobresale el indígena burlándose del español"; "El Güegüense es el pueblo, habla el pueblo y habla por el pueblo, representa la historia"; "es una mezcla de conocimientos"; "es como la representación de 'la gigantona con el enano cabezón' ya que la gigantona representa al español y el enano cabezón al indio; "es la representación de la identidad propia que llevamos dentro; es lo que nos diferencia de otras culturas; "es la picardía y forma de sobrellevar lo que nos oprime, es la forma de buscar cómo sobrevivir y coexistir en las sociedades"; "es el espíritu aventurero y arraigado que poseemos". De acuerdo a estas opiniones de los estudiantes en relación a la interpretación de qué es El Güegüense, se puede deducir que es una figura representativa de nuestra sociedad y que forma parte de la identidad; el cual se refleja en la cotidianidad del nicaragüense.

A como expresa Darcy Ribeiro, la reserva de riquezas en la actualidad es utilizada en la integración del propio ser nacional con una mezcla de dos tradiciones culturales heredadas, que resultan opuestas, por un lado, la contribución europea consistente en instituciones técnicas y en contenidos ideológicos que se ha incorporado en el antiguo patrimonio cultural, redefiniendo el modo de vida y la alienación de la visión de sí y del mundo; por otro, el antiguo acervo cultural, que, a pesar de haber sido drásticamente mismos reducido y traumatizado, han podido mantener algunos elementos, como la lengua, formas de organización social, conjunto de creencias y valores que han permanecido profundamente arraigados en extensos contingentes de la población, además de estilos artísticos peculiares que ahora encuentran oportunidades de reflorecer como instrumentos de autoafirmación nacional (Ribeiro, 1969)

En relación a que si saben quién es el autor de El Güegüense, unos han manifestado que "la obra de teatro El Güegüense es de autor anónimo"; otros dicen que "dentro de todos los estudios que se le han hecho, no tiene autor, no aparece plasmado por quién fue hecho"; otro dijo que "fue un indígena que le trabajaba al gobernador o alguien que vivió la burla que los indígenas le hacían a los españoles y que la sintiera"; otro dice que "lo que conoce es que antes estaba escrito en náhuatl y luego en español y por esa razón se conoce su contenido"; "primeramente el autor fue un indígena, después los tradujo un fraile español 
o un mestizo". Otros estudiantes expresan que "lo escribió algún escritor que se ha dedicado al estudio de las obras literarias"; "no tiene autor, es producto de situaciones expresadas por los artistas o los intérpretes, es decir es popular". De todas estas opiniones se deja ver que la mayoría conoce el significado del Güegüense, pero no conocen su procedencia.

En relación a la pregunta cómo surge el güegüense, expresan que "la obra de teatro El Güegüense surge de la mezcla de las culturas coloniales y las indígenas"; "surge a partir de que el español vino a imponer sus reglas, cuando el indígena se opuso a esas cosas"; "surge como una burla al español que vino a someter a todo un pueblo, pero que no pudo desaparecer su sentir, pensar, su cosmos"; "surge cuando los indios empezaron a imitar a los españoles y se hizo la obra para que fuera una burla de los indios hacia los españoles"; "surge a raíz de la desigualdad e inequidad social por la lucha social ante la opresión por parte de los invasores". Tomando en cuenta las anteriores expresiones, todos coincidieron en que surge en la época de la colonia como una expresión de rebeldía en contra de la opresión española y otros manifiestan desconocer cuál es su origen.

La atracción simultánea de las dos tradiciones, no fueron capaces de fundirse en una síntesis a la que toda su población le confirió un significado, se conservan aún dentro de sí el conflicto entre la cultura original y la civilización europea; algunos de ellos han experimentado una "modernización" dirigida por las potencias europeas que los dominaron, otros se han visto compelidos a promoverla intencionalmente o a intensificarla como condición de supervivencia y de progreso ante el despojo soportado, o bien como medio de superar los obstáculos representados por el atraso tecnológico y lo arcaico de sus estructuras sociales (Ribeiro, 1969)

Al preguntárseles cómo se representa El Güegüense, expresaron que "está representado en cada rincón de Nicaragua, excepto en la Costa Caribe, se puede ver a diario y mucho más en las fiestas patronales de cada pueblo, no solo de Diriamba"; "en la actualidad se representa al Güegüense en las obras teatrales, en sus manifestaciones culturales y religiosas, se representa con un hombre con cara de español y otro con mascara de caballo"; "está representado por un viejo que es un sabio hablador"; "a través de una máscara, con un traje e instrumentos artísticos que se expresa simbólicamente, van expresando el lenguaje popular"; "se representa con un disfraz, música, mascara, chischil y vestimentas; con un baile"; "se representa en las calles en torno a procesión del santo patrono de los diriambinos". En cuanto a cómo se representa manifiestan que su representatividad es a través del baile, la música, la máscara y su vestimenta; otros manifestaron no saber cómo se representa.

Las sociedades humanas explicadas en términos de una sucesión y de procesos civilizatorios, han pasado de una condición generalizada a otros modos, más uniformes y menos diferenciados de proveer su subsistencia, de organizar su vida social, cultural y de explicar sus propias experiencias regidas por sus principios orientados para su desarrollo acumulativo que permite distinguir sus configuraciones en la cultura como parte de sus formaciones socioculturales (Ribeiro, 1969)

En relación a si saben en donde se representa, expresaron que "se da lugar en las fiestas patronales de San Sebastián celebradas el 20 de enero en Diriamba"; otros coinciden que se representa en Managua; la mayoría coincide que se representa en Diriamba; otros desconocen donde se representa. 


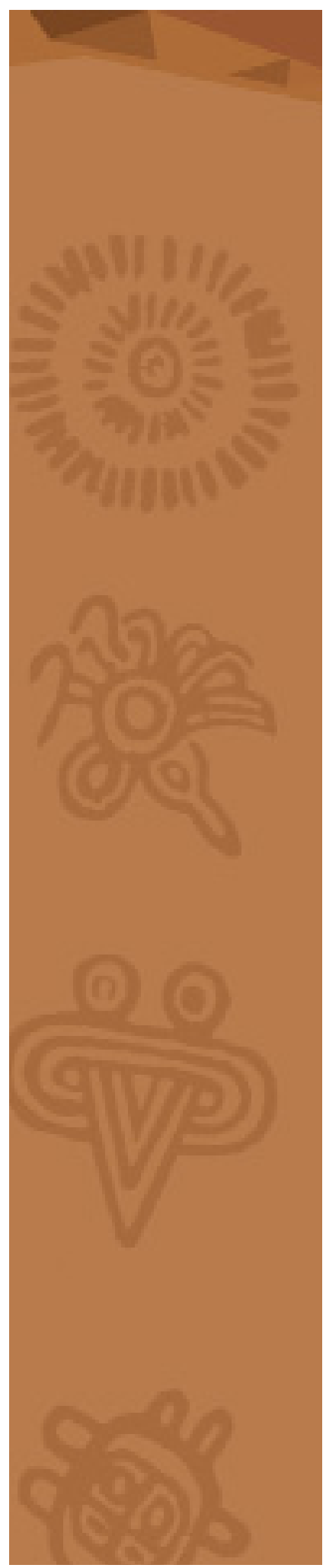

El significado de su contenido para los nicaragüenses está relacionado a que "El Güegüense es una burla a los españoles que creían que tenían dominado al pueblo indígena"; "el contenido es el de ser astuto, burlesco, pero lo que sobresale es el doble sentido que le da a las cosas, como significación a toda la obra teatral"; "significa la sabiduría de un viejo que supo dominar al gobernador; demuestra la astucia, experiencia y conocimiento de todas sus tradiciones"; "significa la inequidad social y su máscara representa al igual que los pasos el llegar de los explotados"; respondieron que su significado es un elemento de identidad nacional que refleja la valentía y buen ánimo frente a la opresión. Consideran que "El Güegüense es nicaragüense, que es una obra que representa nuestra vida, la de los indígenas y de toda la vida de los nicaragüenses".

Recomiendan: "que se dé a conocer la obra de teatro a los jóvenes y niños para que la conozcan más a fondo y que se promueva el estudio del güegüense en las escuelas primarias, que se formen grupos de danzas donde se plasme todo su quehacer, ya que la Asamblea Nacional, junto con la UNESCO lo declararon patrimonio oral e intangible de la humanidad"; "el arte es nuestro y no hay que dejarlo en el olvido, que el gobierno apoye en todo sentido las cosas culturales de nuestro pueblo"; "que no cambie su forma de ser, que sus prácticas y los rituales a sus dioses se perpetúe"; "que como obra se mantenga en nuestra identidad, pero con un estudio más profundo y científico, para otorgarle valor social en donde se tome en cuenta el contenido y aplicarlo en las diferentes transformaciones sociales, defendiendo nuestro derecho y legado cultural"; "que como patrimonio cultural tenga un estudio lingüístico más profundo".

Es importante resaltar que "El Güegüense" es un patrimonio cultural intangible, que merece mantenerlo vivo, más allá de lo folclórico y lo artístico, lo que requiere promover su conocimiento entre los estudiantes universitarios, contribuyendo así en su formación para que profundicen, adopten y refresquen ese conocimiento a través de la practica social y arte. Lo que permitirá la transmisión sistematizada a las futuras generaciones y con ello perpetuar las tradiciones culturales y el fortalecimiento de nuestra identidad. Debemos contribuir a rescatar del "El Güegüense" el reduccionismo artístico y ubicarlo como un elemento central de nuestro quehacer, rescatarlo como un paradigma de resistencia proactiva y propositiva en estos tiempos de estandarización y globalización.

Para ello se requiere, desde las diferentes perspectivas, rescatar ubicando en su justa dimensión las lecciones aprendidas del fenómeno Güegüense, e incorporarlo de forma sistemática y consistente como herramienta de interpretación de nuestra realidad y formulación de nuevas realidades, que generen un bienestar justo, incluyente, humano y ambientalmente sostenible.

Como pueblos conquistados y sometidos de manera total, hemos sufrido un proceso de compulsión europeizante mucho más violento, que proyectó como resultado su completa transferencia propia; los perfiles naturales-nacionales de hoy ya no son originales. No obstante haber sufrido también los efectos del sometimiento, apenas matizaron su figura propia-cultural original con influencias europeas; en nuestra sociedad es precisamente la etnia neoeuropea la que se tiñe con los colores de las antiguas tradiciones culturales, sacando de ellas características que la singularizan; encontraron a nuestras poblaciones estructuradas como formaciones socioculturales totalmente distintas (Ribeiro, 1969) 


\section{Bibliografía}

Berendt, C. Hermann (1977) Manuscrito de "Baile del Güegüense o Macho Ratón. Comedia de los indios mangues en Boletín Nicaragüense de bibliografía y documentación. No. 18, Julio-Agosto 1977, pág. 116-157.

Boletín Nicaragüense de Bibliografía y Documentación. El Güegüense: Patrimonio de la Humanidad. 129. Octubre-Diciembre 2005. Biblioteca “Dr. Roberto Íncer Barquero”. Banco Central de Nicaragua.

Brinton, Daniel Garrison (1883) The Güegüense a comedy ballet in the Nahuatl-Spanish of Nicaragua, Filadelfia, 1883. Traducción de Luciano Cuadra en la Revista "El Pez y la Serpiente" 1968-1969, No. 10, Managua.

Brinton, Daniel Garrison; A.M., M.D. (1883) The Güegüence; A Comedy Ballet. In The Nahuatl-Spanish Dialect of Nicaragua. D. G. Brinton, Philadelphia.

Cuadra, Pablo Antonio (1987) Obras en prosa, El Nicaragüense. San José, Costa Rica. Asociación Libro Libre. Cuba. ANUARIO.

Dávila Bolaños, Alejandro (1974) “Introducción dialéctica”, en Teatro popular colonial revolucionario: El Güegüense o Macho Ratón... Estelí. Tipografía Géminis.

Galich, Manuel (s/f) El Güegüense primer personaje del teatro Latinoamericano.

Lehmann, Walter (1984) Estudio preliminar de El Güegüense o Macho Ratón. Bailete dialogado de la época colonia. Texto en hispano-nahuatl recogido por Walter Lehmann, Managua, Ediciones Americanas.

Lehmann, Walter (1985) "El Güegüense o la esencia mestiza en Nicaragua" en Cuadernos Hispanoamericanos. No. 416, febrero 1985, pp.19-51.

Lehmann, Walter (1991) Versión, estudio y bibliografía en El Güegüense. Bailete dialogado en español-náhuatl de Nicaragua. México, Editorial Limusa, 1991.

Mántica A., Carlos (2001) El Cuecuence o el gran sinvergüenza. Obra maestra de la Picaresca Indoamericana. Managua, Academia Nicaragüense de la Lengua. 134 páginas. (págs., 14 y 16)

Pedrosa, José Manuel (2010) Mestizaje e hibridismo de El Güegüense, Mascarada teatral en náhuat y español de Nicaragua (entre el relato de trickster, la épica, el carnaval y el cuento). Universidad de Alcalá. Biblioteca virtual Universal.

Peña Hernández, Enrique (1994) Folklore de Nicaragua. Masaya, Nicaragua. Mario y Hernaldo Peña - Editores (Pág.138). 


\section{Raíces}

Revista Nicaragüense de Antropología Año 5 No.9| 2021 Enero - Junio

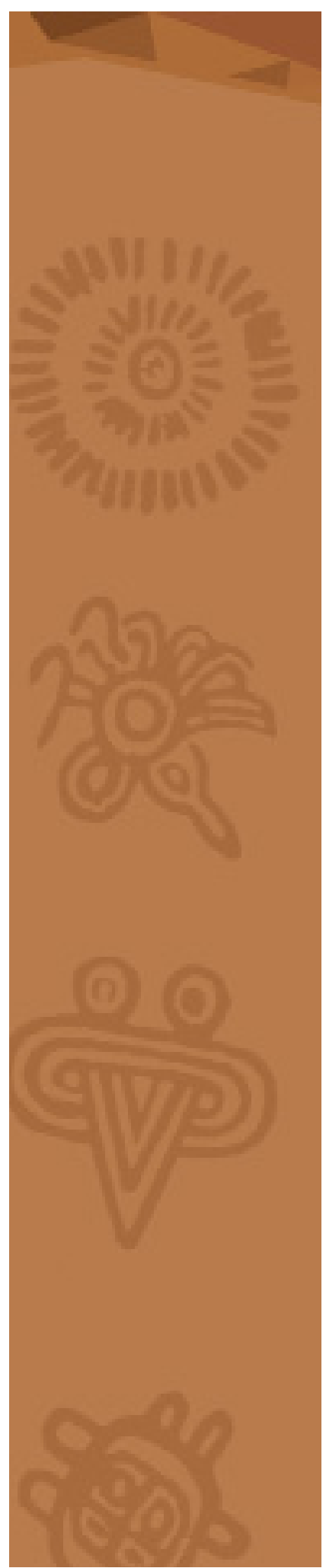

Saballos Ramírez, M. (2013). Los herederos del Güegüense. Temas Nicaragüenses, 4-12.

Selva, Salomón (1931) El Macho-Ratón, en Repertorio Americano. San José. Costa Rica. Vol. 21. Núm. 12. Septiembre, pp. 188-189.

Talavera Talavera, Magdiel Antonio; Valenzuela Ubeda, Keyla del Rosario; Lagos Espinoza, Lucelia del Carmen (2014) Interdisciplinariedad para el análisis de textos literarios. San Sebastián de Yalí - Jinotega. Facultad Regional Multidisciplinaria FAREM - Estelí "Recinto Leonel Rugama”

Tórrez Maradiaga, Yadira Antonia (2020) Análisis comparativo el Güegüense y vuelva Güegüense vuelva de Pablo Antonio Cuadra en los estudiantes de IV año de Lengua y Literatura; Universidad Nacional Autónoma De Nicaragua, UNAN-Managua.

\section{Juana Gricelda Téllez Vado}

Licenciatura en Antropología Social en la Universidad Nacional Autónoma de Nicaragua (UNAN-MANAGUA) Maestría en Antropología y Liderazgo Social en la Universidad Nacional Autónoma de Nicaragua (UNAN-MANAGUA). Conocimientos y experiencia en tareas de acompañamiento y asistencia técnica- metodológica a prácticas de Familiarización, prácticas de Especialización. Desarrollo de temáticas en los contextos rurales y urbanos concernientes dinámicas familiares en relación a la familia, parentesco, relaciones y roles de género; familia comunidad y territorio. Habilidades para el trabajo interdisciplinario, el manejo de relaciones interpersonales y el manejo de grupos. Interés por la actualización profesional. Diseño y realización de estudios sobre situaciones sociales, culturales y económicas de grupos metas para la implementación de programas y proyectos de impacto social. Formulación de modelos de análisis y diseños de investigación. 